\title{
Originals
}

\section{Glycosylation of Glomerular Basement Membrane in Type 1 (Insulin-Dependent) Diabetic Children}

\author{
E. Schober, A. Pollak, H. Coradello and G. Lubec \\ Department of Paediatrics, Division of Neonatology and Inborn Errors of Metabolism, University of Vienna, Austria
}

\begin{abstract}
Summary. Immunoelectrophoresis of glomerular basement membrane antigens in the urine of 20 Type 1 (insulin-dependent) diabetic and 10 healthy children was performed. In 10 of the diabetic children, there was altered $\alpha$-1-mobility, while the other diabetic and normal children showed $\alpha$-2-mobility. After incubation with glucose, glomerular basement membrane antigens in the urine of healthy children showed $\alpha$-1-mobility. Isolated human kidney glomerular basement membrane split products obtained by proteolytic degradation (papain, trypsin, chymotrypsin) were also investigated by immunoelectrophoresis. A difference was observed in the immunoelectrophoretic pattern of native and glycosylated glomerular base-
\end{abstract}

ment membrane split products. A distinct increase of thiobarbituric acid assay positive glomerular basement membrane structures after incubation with glucose provides suggestive evidence for the occurrence of non-enzymatic glycosylation of glomerular basement membrane proteins. Glycosylated glomerular basement membrane proteins may contribute to both functional and morphological changes in diabetic glomerulosclerosis.

Key words: Non-enzymatic glycosylation, glomerular basement membrane, immunoelectrophoresis, Type 1 diabetes mellitus.
Morphological changes of the glomerular basement membrane (GBM) have been described in diabetes mellitus [1]. These changes include thickening of the basal lamina, moth-eaten vacuolated areas and accumulation of electron dense granules. Genetic [2,3], immunological [4] and metabolic disturbances have been discussed [5] in the pathogenesis of diabetic nephropathy.

An analogous mechanism similar to the non-enzymatic glycosylation of haemoglobin and other serum proteins [6-9] found in diabetic individuals with attendant hyperglycaemia, may theoretically affect the GBM glycoproteins $[10,11]$. Recently, a method has been described for the immunoelectrophoretic characterization of human GBM split products in urine [12]. Using this method, we have investigated the excretion of GBM antigens in the urine from diabetic and healthy children. In addition, we have investigated the possibility that nonenzymatic glycosylation is involved in the altered immunoelectrophoretic behaviour of GBM proteins in diabetes. We have also examined the glycosylation of isolated human kidney GBM structures in vitro.

\section{Subjects and Methods}

Twenty children with Type 1 (insulin-dependent) diabetes mellitus were investigated at a summer camp. Clinical details are shown in
Table 1. None of the diabetic patients had proteinuria or evidence of retinal vascular complications on fundoscopy.

For comparison we used urine samples obtained from 10 healthy children (five female, five male), mean age 12.4 years (range 8-14 years). Twenty-four hour urine samples were collected, using merthiolate as a preservative $(1 \mathrm{~g}$ merthiolate $/ 1000 \mathrm{ml}$ urine). Urine samples were dialysed and concentrated 100 -fold by an Amicon stirred Coll 2000 (Amicon, Lexington, USA) using a membrane permeable for molecule weights below 20,000 daltons. Protein concentration was adjusted to $1 \mathrm{mg} / \mathrm{ml}$. This preparation was used for the immunoelectrophoresis and the glycosylation. Immunoelectrophoresis was performed with rabbit-anti-human GBM serum.

At 2 week intervals, rabbits were injected intracutanously with $10 \mathrm{mg}$ dry GBM-preparation mixed with aluminium hydroxide and complete Freund's adjuvant (Difco, Detroit, USA). Two months later, the animals were bled by cardiac puncture. Absorption experiments were performed according to McPhaul and Dixon [13]. The antiserum $(1 \mathrm{ml})$ was incubated with $10 \mathrm{mg}$ of isolated human GBM for $24 \mathrm{~h}$ at $37^{\circ} \mathrm{C}$ and the reactivity was assessed by subsequent immunofluorescence. No positive reaction could be detected on frozen $5 \mu$ kidney sections. When the antiserum was absorbed with GBM, no precipitation lines were found on immunoelectrophoresis. There was no reaction with fibronectin before or after absorption with normal human plasma. No reactivity was found on immunofluorescence with Bowman's capsule, mesangial matrix or muscle basement membrane, but was found with lung basement membrane and placenta basement membrane [14]. As reactivity against human blood leucocytes was excluded, the probability that the antiserum would react with cell membranes is low.

Electrophoresis was performed using an LKB machine (LKB, Brommer, Sweden) and was allowed to run for $45 \mathrm{~min}$, washed and then stained with amidoblack [12]. GBM antigens from the urine of 10 healthy children were incubated with a solution containing $18 \mathrm{~g} /$ 
Table 1. Clinical details of the diabetic children

\begin{tabular}{lllll}
\hline & $\begin{array}{l}\text { Total } \\
(n=20)\end{array}$ & $\begin{array}{l}\alpha \text {-1-mobility } \\
\text { of urinary } \\
\text { GBM antigen } \\
(n=10)\end{array}$ & $\begin{array}{l}\alpha \text {-2-mobility } \\
\text { of urinary } \\
\text { GMB antigen } \\
(n=10)\end{array}$ & $p$ \\
\hline Sex & $\begin{array}{l}11 \text { males } \\
9 \text { females }\end{array}$ & $\begin{array}{l}5 \text { males, } \\
5 \text { females }\end{array}$ & $\begin{array}{l}\text { 6 males, } \\
4 \text { females }\end{array}$ & \\
Age (years) & $12.0(8-16)$ & $12.5(8-16)$ & $11.3(8-13)$ & NS \\
$\begin{array}{l}\text { Duration of } \\
\text { disease (years })\end{array}$ & $5.6(1-10)$ & $5 \quad(2-10)$ & $6.1(1-10)$ & NS \\
$\begin{array}{l}\text { Glycosuria } \\
\text { (g/24 h) }\end{array}$ & $46.9(17-110)$ & $56.8(25-110)$ & $37.1(17-60)$ & NS \\
\hline
\end{tabular}

Data given as mean with range in parentheses; NS = not significant

Table 2. Enzymatic degradation of the glomerular basement membrane

\begin{tabular}{|c|c|c|}
\hline $\begin{array}{l}\text { Enzyme } \\
(0.01 \mathrm{mg})\end{array}$ & $\begin{array}{l}\text { Buffer } \\
(\mathrm{mmol} / \mathrm{l})\end{array}$ & Inhibition \\
\hline Papain $^{\mathrm{a}}$ & $\begin{array}{l}\text { 1/15 phosphate } \\
0.005 \text { cystein } \\
0.001 \text { EDTA } \\
\text { (pH 7.3) }\end{array}$ & $\begin{array}{l}0.001 \mathrm{ml} 0.2 \mathrm{mmol} / 1 \\
\text { sublimate }\end{array}$ \\
\hline Chymotrypsin ${ }^{\mathrm{b}}$ & $\begin{array}{l}\text { 1/15 phosphate } \\
\text { (pH 7.3) }\end{array}$ & $0.001 \mathrm{ml}$ trasylol \\
\hline Trypsin ${ }^{b}$ & $\begin{array}{l}\text { 1/15 phosphate } \\
\text { (pH 7.3) }\end{array}$ & $0.001 \mathrm{ml}$ trasylol \\
\hline
\end{tabular}

Substrate concentration $1 \mathrm{mg} / \mathrm{ml}$, incubation period $6 \mathrm{~h}$ at $37{ }^{\circ} \mathrm{C}$.

a Sigma: Saint Louis, USA, ${ }^{b}$ Serva: Heidelberg, FRG

Table 3. Estimation of ketoamine-linked glucose by the thiobarbituric acid assay of native and glycosylated glomerular basement membrane (GBM) prepared by digestion by various proteolytic enzymes

\begin{tabular}{lccc}
\hline & Papain & Chymotrypsin & Trypsin \\
\cline { 2 - 4 } & \multicolumn{2}{c}{ (nmol 5-hydroxymethyl-furfural/mg protein) } \\
\hline Native GBM & $62.5 \pm 5.8$ & $47.5 \pm 4.9$ & $55.0 \pm 5.3$ \\
Glycosylated & $875.0 \pm 78.1^{\mathrm{a}}$ & $1000.0 \pm 97.9^{\mathrm{a}}$ & $1225.0 \pm 113.4^{\mathrm{a}}$ \\
GBM & & & \\
\hline
\end{tabular}

Results expressed as mean \pm SEM of four experiments;

${ }^{\mathrm{a}} p<0.01$
$100 \mathrm{ml}$ glucose and merthiolate $(1: 10,000)$ as conservating agent for 10 days at $37^{\circ} \mathrm{C}$ in the dark. Dialysis against distilled water was performed in the cold overnight $\left(4^{\circ} \mathrm{C}\right)$ and immunoelectrophoresis performed. GBM were prepared according to the principle of Krakower and Greenspon [15] as described previously [14] using kidneys from non-diabetic individuals obtained at surgery or within a few hours after death at necropsy. Native and non-enzymatically glycosylated GBM were degraded by proteases as indicated in Table 2 and $10 \mathrm{mg}$ of GBM were used for each experiment. The protein concentration of the split products was adjusted to $1 \mathrm{mg} / \mathrm{ml}$ and used in that concentration for immunoelectrophoresis. Non-enzymatic glycosylation was also performed with $60 \mathrm{mg}$ of native isolated human kidney GBM by the same procedure. Glycosylation of GBM proteins was estimated by the thiobarbituric acid assay of Flückiger and Winterhalter [16] as modified by McFarland et al. [17]. Results are expressed as nmol 5-hydroxymethylfurfural/mg protein.

The unpaired t-test was used for statistical analysis.

\section{Results}

Ten of the diabetic children showed $\alpha-1$-mobility of the urinary excreted GBM antigens on immunoelectrophoresis. All the healthy children demonstrated $\alpha-2-$ mobility, which is usually found in normal individuals over the age of 5 years [14]. The remaining ten diabetic children also had $\alpha$-2-mobility. We did not observe any evidence of intermediate lines or double lines in either the diabetic or healthy children. Figure 1 gives examples of the observed immunoelectrophoretic patterns. The diabetic children with $\alpha$-1- and $\alpha$-2-mobility showed no significant differences in their age or duration of disease (Table 1). There was a non-significant trend towards higher $24 \mathrm{~h}$ glycosuria in the patients with $\alpha$-1-mobility $(p=0.06$ ).

After incubation with glucose to produce non-enzymatic glycosylation, the urinary GBM antigens from the healthy children showed a change in immunoelectrophoretic mobility to the $\alpha$-1-region. The GBM split products resulting from digestion with several proteases formed two precipitation lines, differing from each other in their electrophoretic mobility. After glycosylation, the GBM split products resulting from proteolytic digestion showed differences in immunoelectrophoretic

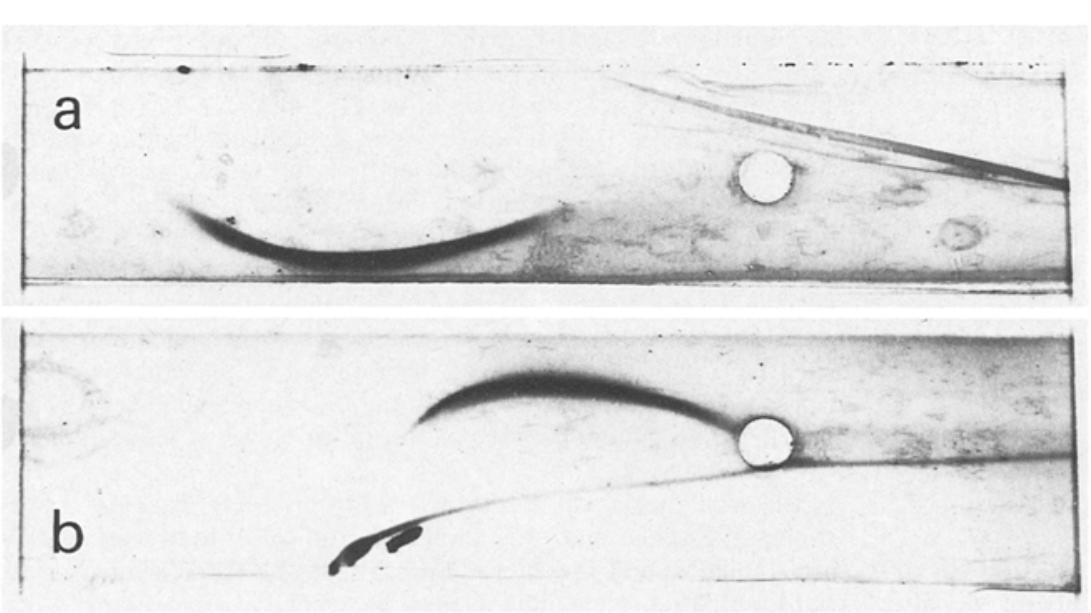

Fig. 1 a and b. Immunoelectrophoretic behaviour of glomerular basement membrane antigen excreted in urine. a $\alpha$-1-mobility which was observed in 10 diabetic children. $\mathbf{b} \alpha$-2-mobility which was observed in 10 of the diabetic and all the healthy children 
behaviour, with a shift to the $\alpha$-1-region. Incubation of native GBM with glucose caused a significant increase of thiobarbituric acid positive material compared with the native GBM split products ( $p<0.01$; Table 3 ).

\section{Discussion}

We have demonstrated altered immunoelectrophoretic behaviour of urinary GBM proteins from healthy children after incubation with glucose, resulting in $\alpha$-1-mobility which was also observed in a number of diabetic children. A change in immunoelectrophoretic mobility was also observed by GBM split products isolated from human kidneys following non-enzymatic glycosylation. The significant increase of thiobarbituric acid assay positive GBM split products after incubation with glucose indicated that non-enzymatic glycosylation of GBM protein had occurred.

Glucose, bound to GBM protein probably by a ketoamine linkage, may be incriminated in pathological alterations of diabetic GBM. Amino acids, e.g. lysine residues, could serve as acceptors for glucose molecules.

We conclude from our study that hyperglycaemia in diabetes might cause non-enzymatic glycosylation of GBM proteins which are excreted in the urine. Whether this increased basement membrane glycosylation contributes causally to the morphological changes and functional disturbances in diabetic nephropathy requires further investigation.

\section{References}

1. Osterby R (1975) Early phases in the development of diabetic glomerulopathy. Acta Med Scand: Suppl 574

2. Paz-Guevara AT, Hsu T, White P (1975) Juvenile diabetes mellitus after forty years. Diabetes 24:559-565

3. Strauss FG, Argy WP, Schreiner GE (1971) Diabetic glomerulosclerosis in the absence of glucose intolerance. Ann Intern Med 75: $239-242$
4. Westberg NG, Michael AT (1973) Human glomerular basement membrane chemical composition in diabetes mellitus. Acta Med Scand 194: 39-47

5. Lundbaek K (1977) Diabetische Angiopathie und Neuropathie. In: Oberdisse K (ed) Handbuch der inneren Medizin, Diabetes mellitus. Springer, Berlin Heidelberg New York, pp 175-187

6. Day FJ, Thornburg RW, Thorpe SR, Baynes JW (1979) Non-enzymatic glycosylation of rat albumin. J Bio Chem 254:9394-9400

7. Dolhofer R, Wieland OH (1979) Glycosylation of serum albumin: elevated glycosyl-albumin in diabetic patients. FEBS Lett 102 282-286

8. Pollak A, Lubec G, Schober E, Simbruner G, Waldhauser F (1980) Total glycosylated hemoglobin and altered $\alpha$-1-acid glycoprotein in juvenile diabetes. IRCS Biochemistry 8: 474-478

9. Pollak A (1980) Die Glykosilierung des Hämoglobins: Bedeutung für den Diabetes mellitus. In: Auerswald W, Baumgarten $\mathrm{K}$, Thalhamer $O$ (eds) Probleme der Perinatologischen Medizin, vol 8. Wilhelm Maudrich Verlag, Wien München Bern, pp 24-40

10. Cohen MP, Urdanivia E, Surma M, Van-YuWu (1980) Increased glycosylation of glomerular basement membrane collagen in diabetes. Biochem Biophys Res Comm 95: 765-769

11. Lubec G, Pollak A (1980) Reduced susceptibility of non-enzymatically glycosylated glomerular basement membrane to proteases. Renal Physiol 3: 4-8

12. Lubec G, Balzar E, Weissenbacher G, Syre G (1978) Urinary excretion of glomerular basement membrane antigens in Alport's syndrome. Arch Dis Child 53: 401-406

13. McPhaul JJ Jr, Dixon FJ (1969) Immunoreactive basement membrane antigens in normal human urine and serum. J Exp Med 130: $1395-1409$

14. Lubec G (1980) Relationship to other human basement membranes. In: Lubec $\mathrm{G}$ (ed) The glomerular basement membrane. Wilhelm Maudrich Verlag, Wien München Bern, pp 43-45

15. Krakower CA, Greenspon SA (1951) Localisation of the nephrotoxic antigen within the isolated renal glomerulus. Arch Path 51: 629-639

16. Flückiger R, Winterhalter KH (1976) In vitro synthesis of hemoglobin $A_{1 c}$. FEBS Lett 71: 356-360

17. McFarland KF, Catalano EW, Day JE, Thorpe SR, Baynes JW (1979) Nonenzymatic glycosylation of serum proteins in diabetes mellitus. Diabetes 28: 1011-1014

Received: 9 January 1981

and in revised form: 9 July 1982

E. Schober

Universität-Kinderklinik Wien

Währingergürtel 74-76

A-1090 Wien, Austria 